\title{
La cuestión jornalera entre dos crisis: condición inmigrante, desafiliación y riesgo de contagio ${ }^{1}$
}

\author{
Andrés Pedreño Cánovas ${ }^{2}$
}

Recibido 15/05/2020; Aceptado 25/07/2020.

Resumen. En la crisis sanitaria por la COVID-19 los asalariados agrícolas han tenido una notable visibilidad. Por un lado, una visibilidad que exaltó su función central en el abastecimiento de alimentos durante los meses que duró la estrategia del confinamiento decretada por el estado de alarma del gobierno español para afrontar la crisis sanitaria generada por el contagio del virus. Por otro lado, una visibilidad negativa derivada de su presencia en múltiples "brotes" víricos y contagios durante el periodo del post-confinamiento denominado "nueva normalidad". Ambos procesos de visibilización, en su positividad y negatividad, y en la medida que quedan en la superficialidad del tratamiento mediático, se resisten a revelar el complejo haz de interdependencias sociales que definen la condición social del asalariado agrícola en las sociedades del sur de Europa. Este artículo aborda las condiciones sociales que modelan y hacen comprensivas ambas formas de visibilización de los asalariados agrícolas en la crisis sanitaria.

Palabras clave: trabajo de los asalariados agrícolas; crisis económica y crisis sanitaria.

\section{[en] The seasonal labour issue between two crises: immigrant condition, social exclusion and risk of contagious}

\begin{abstract}
In the health crisis caused by COVID-19, agricultural employees have had a notable visibility. On the one hand, a visibility that exalted its central role in the supply of food during the months that lasted the confinement strategy decreed by the state of alarm of the Spanish government to face the health crisis caused by the spread of the virus. On the other hand, a negative visibility derived from its presence in multiple viral "outbreaks" and infections during the post-confinement period called "new normal". Both processes of visibility, in their positivity and negativity, and to the extent that they remain in the superficiality of the media treatment, resist revealing the complex bundle of social interdependencies that define the social condition of the agricultural worker in the societies of southern Europe. This article addresses the social conditions that shape and make both forms of visibility of agricultural worker comprehensive in the health crisis.
\end{abstract}

Keywords: agricultural wage labor; economic crisis and health crisis.

Sumario: Introducción. 1. Trabajar en las cadenas globales agrícolas: crisis de 2008, devaluación interna y trabajadores inmigrantes. 2. Conflictos en la cadena global antes de la crisis sanitaria: precios, movilización agrícola y subida del SMI. 3. Crisis sanitaria de 2020: de trabajadores esenciales a trabajadores de riesgo. 3.1. Enclave de frutas y hortalizas de la Región de Murcia: trabajadores "esenciales" en el contexto de una negociación colectiva marcada por el "desprecio" a los derechos de los trabajadores. 3.2. Los asentamientos informales de los enclaves de invernadero de Almería y de los campos de fresa en Huelva: la negación del cuidado. 3.3. La movilidad territorial de los jornaleros: la campaña de la fruta en Lleida y el contagio del virus. 4. Conclusiones. Bibliografía.

Cómo citar: Pedreño Cánovas, A. La cuestión jornalera entre dos crisis: condición inmigrante, desafiliación y riesgo de contagio. Sociología del Trabajo, nº96 (2020), 1-15.

\footnotetext{
El origen de este artículo es una intervención en el Panel Virtual "Trabajo Agrario, Desigualdades y Ruralidad frente al COVID-19", organizado por el GT sobre Trabajo Agrario de CLACSO el pasado 15 de julio. Un planteamiento muy preliminar se publicó en el Blog "Sociología en Cuarentena”, con el título "De Vueltas con la Cuestión Social". Véase https://sociologiaencuarentena.tumblr.com/

2 Departamento de Sociología de la Universidad de Murcia y Colectivo-Blog "Sociología en Cuarentena".

E-mail: andrespe@um.es)
}

Sociol. trab. n॰96 (2020): 1-15 


\section{Introducción}

En este periodo de pandemia global que estamos experimentando en nuestros cuerpos como sociedad, los asalariados agrícolas han tenido una notable visibilidad. Por un lado, una visibilidad que exaltó su función central en el abastecimiento de alimentos durante los meses que duró la estrategia del confinamiento decretada por el estado de alarma del gobierno español para afrontar la crisis sanitaria generada por el contagio del virus COVID-19. Por otro lado, una visibilidad negativa derivada de su presencia en múltiples "brotes" víricos y contagios durante el periodo del post-confinamiento denominado "nueva normalidad".

Ambos procesos de visibilización, en su positividad y negatividad, y en la medida que quedan en la superficialidad del tratamiento mediático, se resisten a revelar el complejo haz de interdependencias sociales que definen la condición social del asalariado agrícola en las sociedades del sur de Europa. Precisamente la labor de la sociología consiste en "iluminar" esas condiciones sociales que modelan y hacen comprensivas ambas formas de visibilización de los asalariados agrícolas en estos meses de crisis sanitaria.

Este artículo parte del convencimiento de la necesidad y urgencia pública de abordar la condición social del asalariado agrícola. Dado que se están planteando muchas cuestiones problemáticas en torno a esta figura social -falta de reconocimiento, racismo, sobrexplotación laboral, población de riesgo de contagio-, quizás es el momento propicio para que la numerosa investigación que venimos acumulando sobre la realidad laboral de campo español desde hace mucho tiempo (Pedreño, 1999) sea puesta a disposición del debate público con el propósito de dotar a los agentes implicados de razones argumentativas que permitan una salida de la controversia por el lado de la justicia y los derechos, antes de que se impongan las visiones de aquellos que quisieran hacer realidad aquel proyecto delirante pergeñado hace veinte años por el alcalde de Elejido, sr. Juan Enciso, durante los trágicos acontecimientos racistas del año 2000: "a las ocho de la mañana los necesitamos a todos, a las ocho de la tarde sobran" (Checa y Arjona, 2005). Siempre con las cautelas que nos enseñó Zygmunt Bauman:

Se ha dicho que la sociología es el poder de los que no tienen poder. Pero no siempre es así. Nada garantiza que por haber adquirido cierta comprensión sociológica uno pueda eliminar o vencer la resistencia de las "duras realidades" de la vida; el poder de la comprensión no basta para enfrentar las presiones de la coerción que acompañan al resignado y sumiso sentido común. Pero si no fuera por esa comprensión, la posibilidad de manejar bien la propia vida y de que las condiciones de vida compartidas se manejen colectivamente sería menor aún (Bauman, 1994: 23).

El presente artículo traza un recorrido sobre la cuestión del asalariado agrícola desde la crisis económica de 2008 hasta la presente crisis sanitaria. En el primer apartado, se analiza la inserción del subsector de frutas y hortalizas en la cadena global de mercancías y sus implicaciones en términos salariales. En segundo lugar, se aborda la conflictividad agraria por el precio de los productos que se desarrolló en los primeros meses de 2020. En el tercer apartado, se analiza la situación de los asalariados agrícolas durante la crisis sanitaria de la COVID-19. Finalmente, en las conclusiones, se enmarca la problemática analizada como parte de la cuestión social de nuestro tiempo.

\section{Trabajar en las cadenas globales agrícolas: crisis de 2008, devaluación interna y trabajadores inmigrantes}

Desde al menos la década de los 90 diferentes analistas constataron la emergencia de una agricultura salarial en detrimento de la tradicional agricultura sostenida sobre la explotación familiar (Etxezarreta, 1994). El caso más paradigmático de este cambio lo constituyen los enclaves de agricultura intensiva de producción de frutas y hortalizas en fresco para mercados de exportación, los cuales se han desarrollado principalmente en la vertiente mediterráneo-atlántica española.

Estos enclaves tuvieron un importante despliegue con la entrada de España en la Comunidad Económica Europea (1986) y la constitución del Mercado Único Europeo (1992). Según los datos de comercio exterior del gobierno español, aproximadamente el 50\% del volumen total de producción de fruta y hortaliza se destina a la exportación, y en algunas orientaciones como la hortaliza de invernadero, la lechuga o los cítricos se eleva al $70 \%$, lo cual posiciona a este subsector como el principal exportador dentro del conjunto del comercio exterior agroalimentario ${ }^{3}$.

Con la expansión de las agriculturas intensivas de exportación, el ciclo del capital productivo de los enclaves de agricultura intensiva y el ciclo del capital comercial quedaron articulados: "así como el modo capitalista de producción presupone la producción en gran escala, también presupone necesariamente la venta en gran escala, es decir la venta al comerciante, y no al consumidor individual" (Marx, 1984: 130). Esta articulación se produce a través de lo que Gereffi (2005) denomina las cadenas globales de mercancías. Este autor define las cadenas globales como una forma organizativa emergente vinculada con un nuevo proceso cualitativo de integración económica. Distingue dos sistemas de coordinación globales: las cadenas dirigidas por productores y las cadenas dirigidas por compradores o distribuidores. Esta segunda forma es la que encontramos en el subsector de frutas y hortalizas en fresco, que resulta el aspecto más novedoso de la globalización agroalimentaria. Este tipo de cadenas están marcadas por una mayor

https://www.mapa.gob.es/es/agricultura/temas/producciones-agricolas/frutas-y-hortalizas/informacion_general.aspx. Consultado 12/07/2020. 
descentralización y fluidez, pues se trata de comerciales-compradores basados en empresas transnacionales, especializados en grandes cadenas de organización de la distribución comercial agroalimentaria, las cuales mantienen relaciones con los productores que usualmente están localizados a lo largo y ancho de la economía-mundo, en territorios semiperiféricos o periféricos.

Autores como Marsden (1997) y Friedland (2001) han conceptualizado la nueva lógica de organización global de la producción agrícola según los principios de just-in-time, a partir de los cuales la producción se programa de "abajo a arriba" a partir de los pedidos y de los productos ya vendidos. Ello responde a la centralidad que adopta el consumo en la ordenación económica a través de la distribución comercial, la cual penetra profundamente en la producción, con disposiciones, normas y estándares que determinan las características de los productos y el modo en que estos han de llegar a los mercados.

Las relaciones jerarquizadas de poder son un elemento estructural de la morfología de la cadena. Se trata de una relación desigual entre una distribución globalizada y una producción localizada que plantea continuamente presiones de mercado para los productores. Las movilizaciones de los principales sindicatos agrarios de enero-marzo de 2020 son un síntoma de estos desequilibrios (analizaremos estas movilizaciones en el siguiente apartado).

La cadena agroalimentaria, como todas las cadenas de valor, impone a los actores sociales que la integran -capital productivo y capital mercantil o comercial- una lógica del intercambio si quieren sobrevivir. La investigación realizada por Marx sobre las relaciones entre el ciclo de circulación (capital comercial) y el ciclo de la producción (capital productivo) sigue siendo magistral para entender esa lógica de intercambio": "El capitalista vuelca a la circulación, en forma de dinero, menos valor que extrae de ella, porque vuelca más valor en forma de mercancía del que ha retirado de ella en esta forma. En la medida en que opera meramente como personificación del capital, como capitalista industrial, su oferta de valor en mercancías es siempre mayor que su demanda de valor en mercancías. [...] el capitalista tiene, en efecto, que "vender más caro de lo que compró", pero esto sólo lo logra, precisamente, porque mediante el proceso capitalista de producción ha transformado la mercancía que compró, más barata porque su valor era menor, en una mercancía de valor mayor, y por ende más cara. Vende más caro, no porque venda por encima del valor de su mercancía, sino porque vende una mercancía cuyo valor supera la suma de valor de los ingredientes que la produjeron" (Marx, 1984: 137-138).

Dada esta lógica, tanto los agricultores más grandes y capitalizados como los más pequeños y descapitalizados tratan de cumplir con el principio que rige los flujos en la cadena: tratar de vender cara la propia mercancía y comprar la mercancía ajena barata (lo cual incluye la fuerza de trabajo entre otros ingredientes). Este principio es el que siguen las relaciones de los supermercados con los consumidores e igualmente es el que se establece entre los productores agrarios y las cadenas de distribución. En definitiva, la articulación del capital productivo y comercial posibilita el que no haya una pérdida del valor del producto agrícola. Como tanto los productores como los comercializadores hacen lo mismo, el valor de compra y el de venta de las mercancías se ajustan a la suma de los valores contenidos en ellas. Ahora bien, y a diferencia de los teóricos de las Cadenas Globales de la Mercancías, no compartimos en que el beneficio se genere por la desigual distribución de posiciones en la cadena. El valor se gana con la generación de plusvalor en la explotación del trabajo. El plusvalor deviene justamente de haber pagado la fuerza de trabajo, ya sea asalariada o autónoma a su valor (esto es, cuando los capitalistas y trabajadores tratan de comprarla y venderla por lo que vale).

La diferencia entre el trabajo necesario y el excedente para generar el plusvalor se produce tanto a través de la relación salarial como en las pequeñas explotaciones. A modo de tipos-ideales, habría tres configuraciones capital-trabajo de generación de plusvalor: $1^{\circ}$ ) los pequeños y medianos agricultores que incrementan la autoexplotación de trabajo propio y familiar, una respuesta cada vez más inviable en un contexto en el que desde hace décadas se aprecia una progresiva desvinculación y desagrarización familiar (Arnalte, Camarero y Sancho, 2006); $2^{\circ}$ ) los pequeños y medianos agricultores que compatibilizan la autoexplotación, a menudo mediando relaciones de paternalismo laboral, del trabajo propio y/o familiar con la explotación de pequeñas plantillas de mano de obra asalariada, y $3^{\circ}$ ) los agricultores más grandes y capitalizados, cuya lógica empresarial les ha permitido instituir una organización racional del trabajo sobre la base de la relación salarial como relación básica de explotación. Estos últimos utilizan mecanismos variados para abaratar el valor de la fuerza de trabajo: salarios bajos, contratos eventuales, horas extraordinarias no pagadas, reclutamiento a través de Empresas de Trabajo Temporal, economía sumergida, etc.

En los enclaves de agricultura intensiva se anudan estrechamente los flujos de capital y los flujos migratorios. A través de las migraciones internacionales se han cubierto las crecientes necesidades de trabajo asalariado que exigen los cultivos (plantación, recolección y otras tareas) y el manipulado o confección del producto en los almacenes. Hoy es un hecho la condición inmigrante de la mayor parte de los asalariados agrícolas, al menos en los nuevos enclaves de agricultura intensiva (Pedreño y Riquelme, 2006). La cantidad de trabajadores llegados a través de los flujos

\footnotetext{
Hemos de precisar que cuando Marx habla de "capital industrial" lo hace en términos genéricos para referirse al conjunto de la producción, sin diferenciar entre sector agrario y sector industrial. De hecho, Marx para ilustrar el ciclo global del capital utiliza a menudos ejemplos que muestran la inserción del sector agrario en el mismo: "Una de las peculiaridades más ostensibles del proceso cíclico del capital industrial, y por ende también de la producción capitalista, es la circunstancia de que, por una parte, los elementos constitutivos del capital productivo provienen del mercado de mercancías, y constantemente hay que renovarlos a partir del mismo, hay que comprarlos como mercancías; por otra parte, el producto del proceso laboral surge de éste como mercancía y constantemente hay que venderlo de nuevo como mercancía. Compárese, por ejemplo, a un moderno arrendatario de las Tierras Bajas escocesas con un pequeño campesino continental a la antigua. El primero vende todo su producto y por eso también tiene que reponer todos los elementos del mismo, incluso la simiente, en el mercado; el otro consume directamente la mayor parte de su producto, compra y vende lo menos que puede, produce él mismo, en la medida de lo posible, aperos, vestimenta, etc.” (Marx (1984: 135).
} 
migratorios y su diversidad de procedencias les han dado un característico cosmopolitismo a estos territorios. La vulnerabilidad de esta mano de obra ha sido también un importante mecanismo de devaluación salarial en los enclaves productivos de frutas y hortalizas (Pedreño, 1999).

La vulnerabilidad ha sido un rasgo estructural del trabajo dado que la condición inmigrante de los asalariados agrícolas conllevó un estatuto de ciudadanía frágil. Esta vulnerabilidad se expresó en todas las facetas de la vida del trabajo inmigrante, pero muy especialmente en el mercado laboral.

Los empleadores tuvieron muy buenas razones para propiciar un proceso de etnificación del trabajo agrario que les permitiera resolver la incertidumbre del reclutamiento de mano de obra (Pedreño, 2014). Ha de tenerse en cuenta que la expansión de los cultivos expansivos y la constitución de "la huerta de Europa" en la vertiente mediterráneo-atlántica española se produjo a finales de los 80 e inicios de los 90 (entrada CEE y Mercado Único Europeo), justo en un contexto en el que la modernización general del país estaba posibilitando el trasvase de las tradicionales bolsas de jornalerismo del sur hacia otros sectores de la economía, planteando un problema de escasez de mano de obra en las exitosas agriculturas de primor. De tal forma que las migraciones internacionales terminarían siendo el recurso indispensable para afrontar este problema.

Por otro lado, la inserción periférica de los enclaves agrícolas en las cadenas globales plantea continuamente tensiones sobre los precios de los productos. Por ello, los bajos salarios y una vinculación contractual de carácter eventual o temporal son rasgos inherentes al modelo laboral de los cultivos intensivos. Esta devaluación interna se ha logrado gracias al estatuto precario y vulnerable de ciudadanía de los trabajadores inmigrantes, así como también a través de la formación de un "ejército de reserva" estratificado o segmentado étnicamente, gracias a las múltiples pertenencias nacionales de los trabajadores inmigrantes, que ha permitido contener el crecimiento de los salarios y, en general, unas condiciones muy precarias en las relaciones laborales del campo.

La figura del "trabajador pobre" ha sido una característica permanente en el modo de inserción laboral de los trabajadores inmigrantes en el campo español. Esto ha planteado evidentes problemas de integración social y de convivencia ciudadana. Los conflictos de carácter racista como el que aconteció en El Ejido (Almería) en el año 2000, aunque no han sido habituales, revelan las dificultades en la convivencia ${ }^{5}$. Se podría afirmar que ha habido una convivencia pacífica con múltiples líneas de diferenciación y segregación social.

En la última década, la situación de los trabajadores agrícolas ha venido desestabilizándose en profundidad como efecto consecutivo de la crisis económica de 2008 y más recientemente de la crisis generada por el impacto de la pandemia global. La crisis económica de 2008 impactó sobre los asalariados agrícolas de una doble forma (gráfico 1). Por un lado, entre 2008-2012 se convirtió en un "refugio" ocupacional para los numerosos desplazados hacia el desempleo en sectores como la construcción o los servicios descualificados. Por otro lado, la crisis parece haber contribuido a incrementar la presencia de población extranjera en agricultura. Desde 2012 observamos que los afiliados extranjeros al Sistema General Agrario de la Seguridad Social han experimentando un importante crecimiento alcanzando el 30\% en 2019 (gráfico 1).

GRÁFICO 1. Evolución de los trabajadores afiliados extranjeros y no extranjeros al sistema agrario dela Seguridad Social

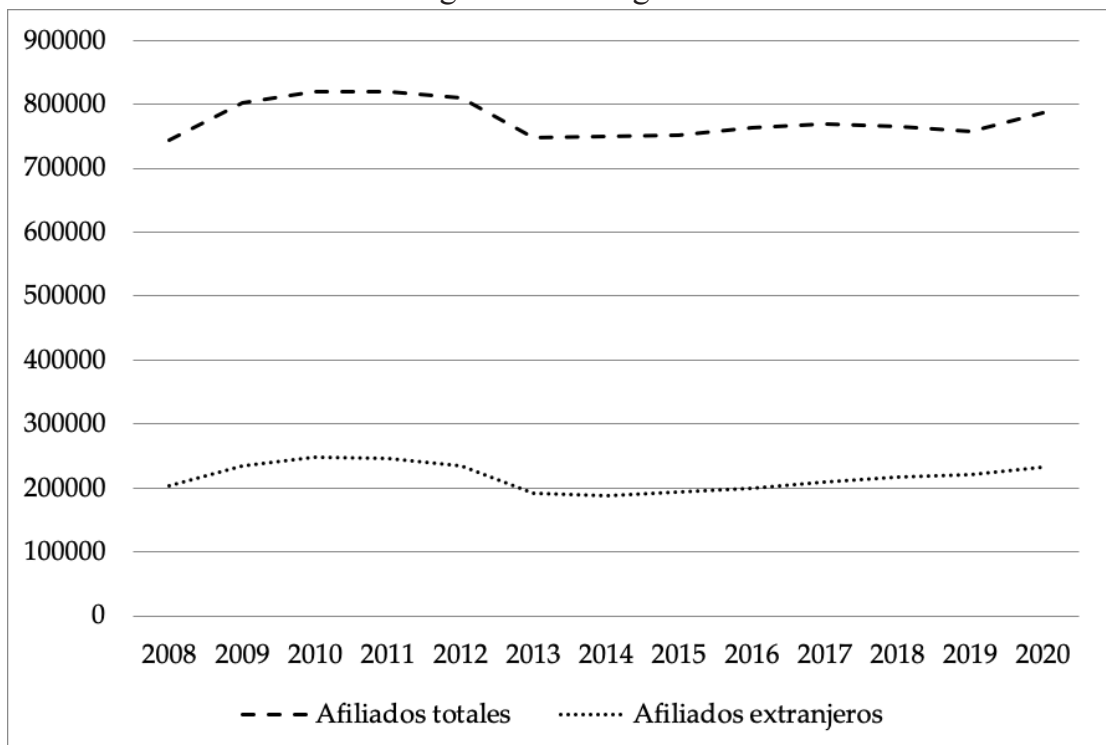

Fuente: Elaboración propia. Ministerio de Trabajo, Migraciones y Seguridad Social, Estadísticas de Afiliación. Los datos corresponden a medias anuales, a excepción del 2020 corresponde al mes de mayo. Hasta el 2012 la curva representa los afiliados al Régimen Especial Agrario y a partir de ese año los datos son los afiliados en el Sistema General Agrario.

\footnotetext{
"El "apartheid" sobrevive en El Ejido. Un año después de los ataques xenófobos los líderes magrebíes han huido y hay bares prohibidos para los inmigrantes" (El País, 4 de febrero de 2001).
} 
El mercado laboral de los asalariados agrícolas se convirtió en un "refugio" étnicamente diferenciado, pues incrementó la presencia de trabajadores extranjeros -también las mujeres inmigrantes experimentaron un crecimiento importante-. Si desagregamos por nacionalidad (gráfico 2), los trabajadores de procedencia africana adoptaron una posición predominante en el sector, particularmente los marroquíes. Mientras los latinoamericanos progresivamente van saliendo del sector, los europeos -búlgaros y rumanos- se recuperan a los niveles anteriores a la crisis. La "africanización" del trabajo asalariado agrícola es uno de los efectos de la crisis abierta en 2008. Casi un 40\% de los afiliados extranjeros al Sistema General Agrario de la Seguridad Social son de nacionalidad marroquí en 2019.

GRÁFICO 2. Evolución de los trabajadores afiliados extranjeros al sistema agrario de la Seguridad Social según principales nacionalidades

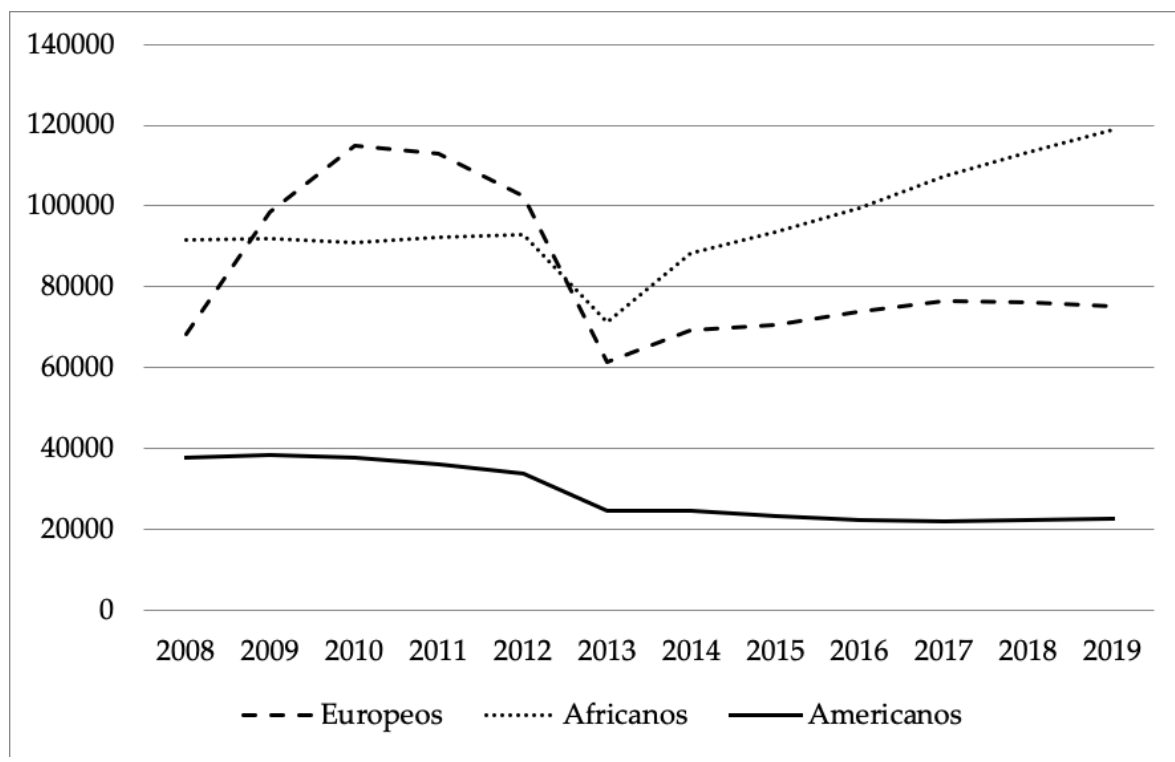

Fuente: Elaboración propia. Ministerio de Trabajo, Migraciones y Seguridad Social, Estadísticas de Afiliación. Los datos corresponden a medias anuales. Hasta el 2012 la curva representa los afiliados al Régimen Especial Agrario y a partir de ese año los datos son los afiliados en el Sistema General Agrario.

La proliferación de las Empresas de Trabajo Temporal ha sido uno de cambios más significativos en las relaciones laborales del campo español y ello tiene que ver con las facilidades otorgadas por la Reforma Laboral de 2012. También el recurso cada vez más frecuente por parte de los empresarios agrícolas de los convenios de empresa, en detrimento de la negociación colectiva, es otro de los efectos a destacar de aquella reforma laboral que ha debilitado aún más la relación salarial en el campo. Podemos afirmar que existe una correspondencia entre, por un lado, la devaluación salarial propiciada por la Reforma Laboral de 2012 como estrategia económica para encarar los efectos de la crisis (Uxó, Febrero y Bermejo, 2015), y por otro, la "africanización" del flujo migratorio que se observa desde la crisis, y muy particularmente de los trabajadores marroquíes, lo cual posibilita ahondar en la vulnerabilidad del trabajo, pues precisamente los estratos más bajos de la etnoestratificada estructura ocupacional agraria han venido siendo ocupados por africanos y marroquíes (Pedreño, 2005). El despliegue que se ha observado en las relaciones laborales del campo hacia el acrecentamiento de la externalización del trabajo mediante el recurso intensivo a las Empresas de Trabajo Temporal, e inclusive hacia una mayor informalización de las prácticas laborales (destajos, economía sumergida, etc.), tiene que ver con esta dinámica de etnoestratificación (Gadea, Pedreño y Castro, 2017).

El incremento del accidente de trabajo in itinere es el indicador más claro de esta degradación de las relaciones del trabajo en el campo. Al igual que mostramos en otro momento de intensificación del uso de la vulnerabilidad del trabajo inmigrante (Castellanos y Pedreño, 2001), de nuevo un trágico accidente de trabajo ocurrido un 26 de abril de 2016 revelaba la nueva estructura de la organización social del trabajo en los enclaves de agricultura intensiva, en este caso, en el enclave de la Región de Murcia. Ese día, el accidente de una furgoneta de una Empresa de Trabajo Temporal que desplazaba jornaleros a la recolección de las cosechas de Cartagena a Águilas (a unas dos horas de distancia) se saldó con cinco trabajadores muertos y tres heridos, todos ellos de nacionalidad marroquí. Este caso de nuevo reveló cómo trabajan los inmigrantes en el campo: destajos, movilidad a deshoras, fatiga y cansancio, informalidad de la relación de empleo, etc. ${ }^{7}$

\footnotetext{
Los empleadores han utilizado las diferenciaciones etnonacionales para segmentar el mercado laboral agrícola, incentivando la competencia interétnica con el fin de disciplinar la mano de obra y contener los salarios. También los propios colectivos inmigrantes han utilizado la etnicidad como estrategia para ganarse "la estima de los hombres" (Bourdieu, 1999) de la sociedad dominante y de los empleadores frente a "los otros" competidores.

"Un accidente en Lorca de una furgoneta causa cinco muertos. Las víctimas son trabajadores del campo de nacionalidad marroquí que iban a Águilas" (https://elpais.com/politica/2016/04/26/actualidad/1461654066_534097.html)
} 
En definitiva, desde hace décadas es incuestionable la centralidad del trabajo aportado por la población extranjera inmigrante en "la huerta de Europa" a la hora de cubrir las necesidades de mano de obra asalariada del sector y hacer posible el dinamismo productivo y exportador que este sector tiene para la economía española. Sin embargo, esa centralidad no se reconoce ni en el salario, ni en las condiciones laborales y de vida, dado que es parte de la devaluación salarial impuesta por la lógica del beneficio.

A menudo esta población sufre habitualmente dinámicas de socioestigmatización, cuando no directamente de racismo. El hecho de que, en las últimas elecciones generales, un partido como Vox que se presentaba con un discurso abiertamente xenófobo de rechazo a la inmigración, obtuviera tan abultados resultados en las áreas de agricultura intensiva con una mayor presencia de mano de obra extranjera resulta muy significativo de las tensiones que laten en estos territorios (Fernández, 2017). Una problemática profunda de reconocimiento (y de desprecio) del estatuto de estos trabajadores existe en estos territorios. Un desprecio que empieza desde el mismo momento en el que las personas inmigrantes no pueden ejercer el derecho al sufragio universal para defenderse de aquellos que en las campañas electorales laceran el cuerpo social con discursos contra su presencia.

\section{Conflictos en la cadena global antes de la crisis sanitaria: precios, movilización agrícola y subida del SMI}

Antes de adentrarnos en la crisis sanitaria provocada por el virus de la COVID-19, conviene detenerse en la conflictividad agraria que tiene lugar en los meses precedentes, pues constituye el marco interpretativo de los hechos que acontecerán en la condición jornalera en ese otro momento.

Con fecha del 4 de febrero de 2020, el Consejo de Ministros aprueba el decreto de subida del Salario Mínimo Interprofesional (SM) hasta los 950 euros, lo que implica un aumento del 5,5\% sobre la cuantía de 2019, y tiene efectos retroactivos hasta el 1 de enero del presente.

Esta medida es inmediatamente rechazada por las organizaciones empresariales del campo (aunque había sido aceptada por las patronales presentes en la Mesa del Diálogo Social, CEOE y Cepyme), muy especialmente por la patronal de los agricultores más capitalizados, ASAJA (Asociación de Jóvenes Agricultores). Desde estos ámbitos de la patronal agraria se asegura que la medida "va a condenar al cierre de las explotaciones que requieren de más mano de obra para su funcionamiento", ven "inasumible para ninguna explotación dos subidas del SMI consecutivas que en total, han permitido un alza salarial del 29\%" y "avisan de que la medida va a dinamitar la negociación de los convenios colectivos que se está llevando a cabo en todas las zonas productoras" (comunicado de ASAJA). También los grupos empresariales del sector agroexportador se suman a las críticas.

De forma simultánea, presionados por los precios descendentes de los productos agrícolas derivados de los intercambios desiguales en la cadena global de mercancías ${ }^{\mathbf{8}}$, las organizaciones agrarias más representativas del sector (COAG, UPA y ASAJA) convocaron movilizaciones en toda la geografía española entre los meses de enero, febrero y marzo". El decálogo de reivindicaciones de "los agricultores y ganaderos al límite" es muy variado, aunque la reclamación central y prioritaria es la "falta de precios justos" y la "subida de los precios de producción" por los "desequilibrios que aún persisten entre los distintos eslabones de la cadena en la conformación de los precios y la falta de rentabilidad que sufren las explotaciones, que provoca que la gran distribución e industrias sean pocos y poderosos y los agricultores muchos y débiles"10.

Las movilizaciones de los agricultores y ganaderos tuvieron una amplia repercusión en todas las comunidades autónomas. Solamente ASAJA incluyó entre las reivindicaciones de la movilización el rechazo a la subida del Salario Mínimo Interprofesional decretada por el Gobierno ${ }^{11}$. De hecho, las organizaciones de los pequeños agricultores se apresuran a mostrar su desacuerdo con esa reclamación. Otras como la Coordinadora de Organizaciones de Agricultores y Ganaderos (Coag) alertaron de que la subida del Salario Mínimo Interprofesional (SMI) podría suponer un aumento del 50,4\% de los costes laborales para los agricultores al mes, al pasar de 967 euros por trabajador/mes en 2018 a 1.455 euros en 2020. «Sería una puntilla más para el campo que afectaría sobre todo a las explotaciones pequeñas y medianas, es decir a las familiares», destacó el presidente de Coag en la Región de Murcia, Miguel Padilla.

Es precisamente en los enclaves de agricultura intensiva de fruta y hortalizas para exportación donde la patronal del campo muestra una posición más beligerante hacia la introducción de la subida del SMI en los convenios colectivos del campo. Las tensas negociaciones que se están dando en estos meses en la Región de Murcia o en la

\footnotetext{
Vidal Maté, sitúa en un 8,6\% la caída de renta agraria durante 2019. Véase su artículo en El País de 6 de enero de 2020 : "La renta agraria se hunde tras cinco años de subidas. La sequía y los precios bajos redujeron la producción en 2019" (https://elpais.com/economia/2020/01/05/actualidad/1578240782 259655.html).

9 En realidad, el malestar en el campo por la caída de los precios agrícolas venía arrastrándose desde tiempo atrás. En octubre de 2019, los agricultores de Almería y Granada convocaron de forma autónoma "una huelga de hortalizas caídas", es decir, de no venta por debajo del precio de coste: "Huelga de "hortalizas caídas" en los invernaderos por los bajos precios. El paro, al que se han unido subastas y comercializadoras de ambas provincias, ha sido iniciativa de un grupo de agricultores al margen de asociaciones y entidades, a través de redes sociales" (http://www.almeriahoy. com/2019/10/huelga-de-hortalizas-caidas-en-los.html).

10 Disponible en https:/www.upa.es/upa/noticias-upa/2020/3088/. Véase también comunicado de ASAJA: "E1 sector agrario comienza mañana su calendario de movilizaciones con actos de protesta en 11 Comunidades Autónomas" (https://www.asaja.com/publicaciones/el_sector_agrario_comienza manana su calendario de movilizaciones con actos de protesta en 11 comunidades autonomas 7520). Consultado el 12/07/2020.

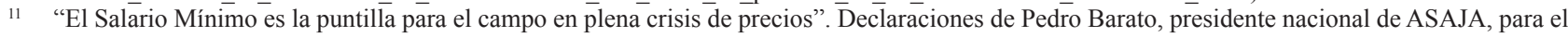
Economista.es (30 de enero de 2020).
} 
zona fresera de Huelva así lo demuestran ${ }^{12}$. Indudablemente en las regiones de agricultura intensiva de la vertiente mediterránea, donde predomina una agricultura empresarial que moviliza un importante contingente de mano de obra asalariada, y en las cuales en las últimas décadas se observa un continuo proceso de centralización de capital en unidades productivas de cada vez mayor dimensión con el consiguiente desplazamiento y pérdida de valor de las de menor tamaño, la movilización estuvo dominada por los grandes empresarios agrícolas. En el Cuadro 1, recogemos una anotación etnográfica de la manifestación del 21 de febrero que tuvo lugar por las calles de Murcia.

\section{CUADRO 1: NOTAS ETNOGRÁFICAS DE LA MANIFESTACIÓN CONVOCADA EN MUR- CIA POR LAS ORGANIZACIONES AGRARIAS, 21 de febrero de $2020^{13}$}

Esta mañana escucho en La Ser a uno de los convocantes de la protesta criticar las supuestas declaraciones "despreciativas" del vicepresidente del Gobierno hacia los agricultores. (Pablo Iglesias había dicho "seguid protestando, lleváis toda la razón").

Me acerco a la manifestación. Es un ruido infernal de bocinas y pitos de camión y tractores. Muchos peatones se tapan los oídos. Es francamente insoportable.

En la cabecera iban los elementos humanos. Ciertamente muchos pequeños y medianos agricultores, pero lo que más se veían era jornaleros "animados" u obligados por sus patronos a participar en la manifestación. También veo representantes de los sindicatos agrarios convocantes y de los partidos que amparan al gobierno autonómico.

Acongoja cruzar la manifestación entre enormes tractores de última gama. Te sientes un infrahumano. Los camiones son también imponentes. A su lado los tractores y camiones más modestos dan cuenta de las diferencias de clase entre unos u otros agricultores. Algunos tractores y camiones van engalanados de banderas españolas. No veo ninguna bandera murciana. También hay banderas de las organizaciones agrarias convocantes.

Fundamentalmente es una manifestación de las máquinas, del trabajo muerto, del capital constante. Lo que se aprecia en esos tractores y camiones es el capital de aquellos que en la carrera competitiva han conseguido incrementar la composición orgánica del capital mediante inversiones continuas en detrimento de su composición viva. Por tanto, lo que prima en la protesta es un agricultor altamente capitalizado. Lo de esta mañana es una exhibición pública de la alta concentración de capital de la producción agropecuaria murciana. Es lo que predomina y lo que empequeñece a los pequeños y medianos agricultores, cuyos artilugios se quedan a la sombra de los grandes tractores y tráileres. También los manifestantes parecen monigotes moviéndose entre estas máquinas móviles (yo mismo me he sentido así).

Infrapresencia de lo humano, hiperpresencia del capital acumulado en máquinas. Infrapresencia del trabajo concreto, hiperpresencia del trabajo abstracto. Es una manifestación reglamentada por la ley del valor de cambio y sus máquinas.

La manifestación refleja con claridad las relaciones sociales dominantes hoy en la producción agropecuaria murciana. La tendencia a la concentración de capital al tiempo que desestabiliza o incluso produce un desclasamiento de los pequeños y medianos propietarios. Estas categorías desestabilizadas albergan un enorme resentimiento hacia el Estado al que culpan de todos sus males: de la subida del SMI, de los precios del agua, de los límites medioambientales, de los precios de los supermercados.

Me salgo de la protesta por las calles adyacentes. Compro fruta en una frutería. Desde aquí se oyen los pitos y bocinas de los camiones. Varios clientes hablan con la tendera y pregunta con queja cuándo se acaba la protesta. Otra señora dice: "no nos quejemos que llevan razón”. Eso mismo es lo que ha dicho el vicepresidente del Gobierno, pienso para mí mismo.

La clave del acuerdo para la subida del SMI, y de su importancia, reside en que se trata de una medida que rompe con la tendencia abierta con la crisis económica de 2008 hacia la devaluación salarial, ese pivote central de la estrategia de austeridad neoliberal consolidado por las reformas laborales del 2010 y del 2012, que generaron recortes del salario medio real superiores al 7\% y que se han cebado en las rentas salariales más bajas, es decir, en el 10\% de los trabajadores que perdieron un $22,5 \%$ de su salario real en el periodo de la crisis hasta el 2015. Su efectividad no será solamente importante a los directamente afectados por el SMI, sino que repercutirá en las escalas salariales más bajas de los convenios impulsándolos al alza. De ahí la importancia de acuerdo para los asalariados agrícolas.

El Catedrático de Derecho del Trabajo, Antonio Baylos, señaló con su habitual precisión la importancia de la subida del Salario Mínimo para los asalariados agrícolas y criticó la posición de la patronal agraria en contra del acuerdo. $\mathrm{Su}$ crítica fue especialmente incisivas con aquellos gobiernos autonómicos socialistas, como el de Extremadura y Castilla La Mancha, que habían respaldado las posiciones de la patronal agraria: “¿Por qué los gobiernos socialistas de dos Comunidades Autónomas como Extremadura y Castilla La Mancha deciden respaldar públicamente con todo su peso político un razonamiento incorrecto y sesgado que coincide con las reivindicaciones de las patronales agra-

\footnotetext{
Por ejemplo, la resistencia a la subida del SMI en la Región de Murcia: https://murciaplaza.com/el-campo-se-rebela-contra-una-nueva-subida-del-salario-minimo; o en las zonas freseras de Huelva: http://agrodiariohuelva.es/2019/05/06/ugt-senala-la-alta-resistencia-de-cumplir-con-lasubida-del-smi-en-el-sector-agrario-de-huelva/. Consultado el 12/07/2020.

13 La Opinión de Murcia, 21 de febrero de 2020 tituló: "Los agricultores protagonizan una manifestación histórica en Murcia". El articulista indicó que "hasta a 7.000 agricultores y ganaderos se han dado cita esta mañana en Murcia con más de 400 tractores y decenas de camiones".
} 
rias del sector, y no se colocan en una posición vindicativa de impulsar los salarios, para que los llamados trabajadores pobres dejen de serlo, aquellos que aun trabajando no pueden hacer frente a sus necesidades y las de sus familias y para dar un impulso redistributivo y equitativo de la riqueza que se produce en este marco territorial? ¿Por qué estos gobiernos que se reclaman de la izquierda social y que forman parte del partido que está en el gobierno y ha avalado la subida del salario mínimo en el 2019 y ahora con acuerdo social en el 2020 abren un flanco de boicot a esa medida social pactada además en el acuerdo de gobierno progresista? ¿Cómo es posible que Fernández Vara y García Page, haciendo un uso incorrecto de los datos de los que se dispone, avalen el discurso neoliberal contra el incremento del salario mínimo, actuando no sólo contra el programa de gobierno, sino también contra el acuerdo alcanzado en el seno del diálogo social? Con ello se sitúan en el mismo espacio que Vox y que Ciudadanos, en una cerrada defensa de un empresariado que busca fundamentalmente subsistir a partir de bajos salarios y de subvenciones públicas. Un modelo de empresa al que estos gobiernos autonómicos deberían precisamente combatir y reformar"14.

En definitiva, en torno a las manifestaciones de las organizaciones agrarias de los primeros meses del 2020 y el debate sobre la subida del SMI aprobado por el Gobierno del PSOE y Unidas Podemos, se aprecian las tensiones específicas de las cadenas globales de mercancías. Por un lado, la tensión entre el capital comercial y el capital productivo por la fijación del precio de los productos agrícolas dentro de una relación de posiciones de poder extremadamente desigual dada la fuerte concentración habida en los últimos años en unas cuantas grandes distribuidoras alimentarias. Por otro lado, el capital productivo que en el campo está fuertemente diferenciado entre pequeños, medianos y grandes agricultores, aunque dependiendo de en qué orientaciones productivas se observa un acelerado proceso de centralización-concentración de capital en torno a grandes unidades de producción con mano de obra asalariada. En la medida que se afianza la tendencia general hacia una agricultura más salarial que familiar, la explotación del trabajo de los asalariados agrícolas es el proceso de generación de plusvalor, por lo que la devaluación salarial deviene una estrategia permanente en el sector agrario.

Esta conflictividad entre clases o posiciones diferenciadas en la estructura agraria del campo español está además cruzada por una fuerte controversia política entre el gobierno de mayoría progresista presidido por Pedro Sánchez y un bloque político de derechas y ultraderecha compuesto por PP-Vox y Ciudadanos que considera ilegítimo al gobierno de izquierdas por requerir del voto de los nacionalistas para mantener la mayoría parlamentaria. Determinados sectores empresariales del campo español no ocultan desde hace tiempo su vinculación con ese bloque de poder de derechas y, en ese sentido, no es casualidad el fuerte apoyo electoral obtenido por el partido ultraderechista Vox en las Elecciones Generales de 2018 en las zonas de agricultura intensiva con fuerte presencia de familias inmigrantes afincadas $^{15}$.

Estos comportamientos políticos de los enclaves agroexportadores son un indicador relevante sobre la existencia de lo que Weber llamaría "cierres sociales" y de cómo "cualidades naturalizadas", como la pertenencia etnonacional, se utilizan "para justificar la exclusión de colectivos sociales enteros de las relaciones de reconocimiento imperantes en la sociedad" (Honneth, 2019: 190). Este cierre naturalizado en la esfera del reconocimiento es un síntoma de unas relaciones más profundas que atañen al funcionamiento del sistema económico: la constitución desde la crisis del 2008 de unas categorías sociales desafiliadas y étnicamente diferenciadas disponibles para la sobreexplotación de su fuerza de trabajo ${ }^{16}$. La crisis sanitaria de 2020 va a terminar iluminando que en los enclaves de agricultura intensiva la organización racional del trabajo está siendo sustituida por una lógica de usurpación o desposesión del valor del trabajo inmigrante, legitimada por la naturalización de sus cualidades y su existencia desafiliada.

\section{Crisis sanitaria de 2020: de trabajadores esenciales a trabajadores de riesgo}

La crisis de 2008 en España desestabilizó a los más vulnerables y los lanzó a los bajos fondos de la desafiliación social. De aquella crisis salimos con una realidad terrible, un 13\% de trabajadores pobres o desafiliados, esto es, trabajadores con trabajos tan precarios e inestables y de salarios tan bajos que ni aun trabajando podían salir de la pobreza (OIT, 2020). Los investigadores de esta problemática, como el sociólogo Rodolfo Gutiérrez, insisten en que las tasas de riesgo de pobreza laboral han de leerse transversamente, de tal forma que así se aprecia la importancia de la pobreza temporal (aquellos que sólo experimentan un periodo de pobreza de uno o dos años de duración) y la pobreza recurrente (los que experimentan periodos de pobreza). Desde el punto de vista de la pobreza temporal, la crisis elevó por encima del 23\% la pobreza temporal, así como también incrementó la pobreza recurrente (Gutiérrez, 2009).

La presente crisis de la COVID-19 ha venido a recordarnos que una sociedad cohesionada requiere de la división social del trabajo para el ejercicio efectivo de la solidaridad colectiva (es la gran enseñanza de Durkheim). En esta

14 https://baylos.blogspot.com/2020/01/la-subida-del-salario-minimo-genera.html. Consultado el 12/07/2020.

15 Los desencuentros entre el gobierno progresista y la patronal agraria son constantes. Si la Ministra de Trabajo, Yolanda Díaz, anuncia que la Inspección de Trabajo investigará "situaciones de esclavitud" y "malos tratos" durante las campañas agrícolas de mayo-junio (El Independiente, 12/05/2020), la patronal agraria pide su dimisión, la tacha de "irresponsable" y considera "inaceptable que se ponga en duda al sector" (ABC, 14/05/2020), críticas que sistemáticamente obtienen el respaldo de líderes regionales y estatales de la derecha política ("López Miras -Presidente autonómico de la Región de Murcia- afea a la ministra de trabajo que insinúe que en el campo hay esclavitud”, la Verdad, 21/05/2020). Resultado de estas Inspecciones han sido algunas operaciones policiales con empresarios agrícolas detenidos por uso ilícito de trabajadores inmigrantes.

16 Desde una perspectiva marxiana, lo que Weber denominaba "organización racional del trabajo" es la extracción de plusvalía como diferencia entre el valor de la fuerza de trabajo y el trabajo excedente. Esto hay que diferenciarlo de la sobreexplotación del trabajo, que es la diferencia entre el valor de la fuerza de trabajo y su precio fijado a través de prácticas de infraempleo y sobreintensificación de los ritmos de trabajo. 
trama de interdependencias, en la que unos y otros nos ligamos por vínculos de dependencia mutua, fue posible la formidable movilización de energías sociales sin la cual la estrategia del confinamiento durante la crisis sanitaria del COVID-19 hubiese sido inviable (Pedreño, 2020). De repente los trabajadores desafiliados devinieron en trabajadores esenciales. Efectivamente, las cajeras de los supermercados, los trabajadores del campo, el personal de la limpieza, los repartidores, en definitiva, los precarizados en estos años de política laboral neoliberal, se convirtieron en "esenciales".

Han sido décadas de neoliberalismo constituyendo lo que Christian Laval y Pierre Dardot (2013) han denominado "el sujeto neoliberal", el cual ya "no debe considerarse a sí mismo como un trabajador, sino como una empresa que vende un servicio en un mercado". De repente, esta crisis vírica actualiza el "trabajo con los otros". Esta afortunada expresión de la socióloga francesa Danièle Linhart (inspirada en Emile Durkheim) (Linhart, 2013) viene a recordarnos que el trabajo siempre está en una relación con la sociedad en su conjunto. Más allá de esa división administrativa entre actividades esenciales y no esenciales, la crisis vírica valoriza el vínculo del trabajo con los otros (con la sociedad) y nos muestra que la supervivencia y sostenibilidad de una sociedad depende de ese vínculo esencial del trabajo con los otros.

La crisis sanitaria ha hecho emerger una paradoja: puedes ser considerado un trabajador o trabajadora "esencial" y al mismo tiempo sufrir unas condiciones laborales altamente degradadas que te convierten de forma permanente en un potencial "desechable". Venimos de décadas en las que el trabajo se redujo a individualismo competitivo, a empresario de sí mismo y en definitiva a un "trabajar sin los otros". Así el trabajo dejó de ser un vínculo privilegiado de la solidaridad social y de la construcción de ciudadanía. Es más, todas las reformas laborales de las últimas décadas han ido socavando los colectivos en el trabajo y enfatizando al individuo, desde la premisa de que el valor de lo colectivo en la división social del trabajo era un peligro para la competitividad (máxime si tenía la ocurrencia de organizarse en sindicatos). El neoliberalismo decretó que el trabajo con los otros, ese vínculo esencial del trabajo con la sociedad, era un arcaísmo. En el mundo de la circulación de las mercancías, el trabajo debía ser una mercancía más en el juego infinito de los intercambios.

En el universo laboral de la larga noche neoliberal, tal y como viene demostrándolo la Sociología del Trabajo, son muchas las actividades productivas en las que se ha cortado este vínculo del trabajo con la sociedad. La citada socióloga Danièle Linhart lleva años en una fecunda trayectoria de investigación indagando sobre esta ruptura. Esta socióloga demuestra cómo se ha ido construyendo sistemáticamente "una identidad de empresa" (Linhart, 1997), pidiéndole a los asalariados una lealtad sin fisura con los objetivos del beneficio económico en detrimento de otras formas de vinculación e identidad: "se podría decir, a grandes rasgos, que la empresa, en la globalización, tiende a cortar el vínculo (simbólico e identitario) entre sus asalariados y la sociedad, y solo deja en pie el vínculo que los une a ella misma en el marco de una relación a menudo incierta. En un mundo del trabajo cada vez más dominado por una gestión sistemáticamente individualizada, los asalariados se ven abocados a perder no solo un modo de vida en el que los colectivos desempeñan un rol potente en la socialización en el trabajo, sino también a cortar el "cordón umbilical" que los liga a la sociedad. Obligados a situarse, en el terreno identitario y simbólico, en un mundo en el que prima mucho más la competencia que la interdependencia, el único don que les queda es el que se entrega a su empresa" (Linhart, 2013: 58).

La desafiliación social es el daño más radical que pueda experimentar la división social del trabajo. Es un cortocircuito profundo en el vínculo entre trabajo y sociedad que precariza la solidaridad colectiva. Tras la finalización el 21 de junio del estado de alarma y la entrada en la "nueva normalidad" se observa cómo muchos de los nuevos contagios habidos tras la pandemia se están dando en espacios laborales como los del trabajo agrícola en donde la precariedad y la desafiliación favorecen la transmisión del virus.

A pesar de algunas voces de alerta, la situación de desafiliación de franjas importantes de los jornaleros inmigrantes afincados en lugares como Huelva o Almería ha estado absolutamente descuidada por parte de la estrategia de salud pública. Como muy acertadamente ha declarado la investigadora del CIDOB, Blanca Garcés, a propósito del brote vírico habido en Lleida y Aragón, agravado por las penosas condiciones de los jornaleros inmigrantes desplazados a la cosecha de la fruta, "no se pueden poner en marcha políticas de salud pública para controlar una pandemia teniendo miles de excluidos del sistema que están durmiendo en la calle" ${ }^{\prime 17}$.

En este sentido es aleccionador lo que sucedió en Singapur con los trabajadores inmigrantes asentados en esta ciudad-Estado. En marzo, cuando empezábamos a reaccionar en los países europeos, Singapur se movilizó rápidamente y consiguió mantener a raya durante semanas sus primeros casos de coronavirus con un modelo elogiado, en sus inicios, por combinar control, vigilancia y contención, así como una fuerte preparación basada en la experiencia previa con el brote de SARS de 2003. Pero se olvidó de sus desafiliados, los más de 300.000 trabajadores inmigrantes procedentes del Sur de Asia que trabajan en la construcción y habitan barrios miserables. El virus se cebó en los desafiliados, de tal forma que al poco de que Singapur entonara su victoria en la lucha contra el virus se encontró con una segunda oleada de contagios sin control precisamente en estos barrios de desafiliados. A mediados de junio, Singapur, que cuenta solo con 5,6 millones de habitantes, había registrado 42.432 casos totales de COVID-19, y según el Ministerio de Sanidad, el 94\%, un total de 40.024, correspondía a personas que residen en los masificados "dormitorios" (es la denominación que reciben los enormes complejos en los que viven los trabajadores extranjeros

${ }^{17}$ En https://www.publico.es/sociedad/explotacion-migrantes-origen-rebrote-lleida.html 
a las afueras de la ciudad, lejos de sus relucientes rascacielos y hoteles de lujo, a cuyo centro urbano van y vuelven del trabajo todos los días amontonados en cualquier medio de transporte) ${ }^{18}$.

El caso de Singapur muestra que, en una crisis sanitaria, la desafiliación social imposibilita la cohesión social, la solidaridad colectiva, la interdependencia de la división social del trabajo y, al final, propicia la transmisión del virus.

En relación a esta tesis, veamos a continuación lo que está sucediendo en varios enclaves de agricultura intensiva de la vertiente mediterráneo-atlántica española.

\subsection{Enclave de frutas y hortalizas de la Región de Murcia: trabajadores "esenciales" en el contexto de una negociación colectiva marcada por el "desprecio" a los derechos de los trabajadores}

Los meses del estado de alarma por la crisis sanitaria coincidieron con la negociación de los convenios colectivos del campo en la Región de Murcia que afectan a unos 40.000 asalariados agrícolas (25000 trabajadores del convenio agrícola y 15000 del convenio de cosecheras de tomate y lechuga). El principal punto de desacuerdo ha sido la actualización de los salarios en relación a la subida del SMI: "Sepa todo el mundo que el salario hora de las trabajadoras del campo murciano actualmente es de $6.93 €$ la hora, que es exactamente el Salario Mínimo Interprofesional de 2019, porque a las patronales murcianas del agro -COAG, ASAJA, PROEXPORT, APOEXPA- no les ha dado la gana todavía de aplicar ni siquiera el SMI de 2020, aunque desde CCOO se lo reclamamos en febrero, un mes antes de que todo esto estallara. Ni de incrementar los salarios al ritmo en el que sí lo estamos consiguiendo en otros sectores: el metal, la química, la administración, a todos ellos les hemos logrado subir en torno al $2 \%$ en los últimos dos o tres años. Pero en el campo ha sido imposible. Con esos sueldos no se llega ni a mileurista. Eso, en un sector en el que, además, no se trabaja todos los meses del año, pues se trata en su mayor parte de fijos discontinuos. No paro de ver nóminas anuales de escasamente 11.000, 12.000 euros en la agricultura murciana. Por debajo del salario mínimo. ¿Qué familia puede vivir con eso? ¿Cómo es posible que la agricultura, recuerden, el motor económico de la región, pague tan mal a las personas que trabajan en ella? Recuerden también esto: encima de todo, son esenciales. Lo ha dicho el Gobierno de la nación en un BOE" (José Ibarra, Secretario Comarcal de CCOO del Campo de Cartagena) ${ }^{19}$.

Los desafiliados jornaleros inmigrantes a los que se les consideró trabajadores esenciales durante los meses del confinamiento continúan sin que la patronal agraria les reconozca unas condiciones laborales dignas. ¿Cómo este empresariado que se niega a sacar de la vulnerabilidad y/o de la desafiliación social a miles de trabajadores agrícolas, que siguen haciendo una labor esencial, va a tomarse realmente en serio una política de prevención del riesgo de contagio del virus entre los jornaleros que pasa necesariamente por dignificar sus condiciones de vida, hábitat y salario?

Mientras tanto varios brotes de coronavirus han tenido como centro empresas hortofrutícolas. Por un lado, el llamado "brote de Bolivia", en referencia a un trabajador llegado de Bolivia con la fiebre vírica y que generó un importante contagio en la empresa hortofrutícola en la que operaba. Según las autoridades sanitarias, este contagio se produjo por que el afectado no cumplió con la cuarentena obligada y extendió el virus en la empresa hortofrutícola donde operaba. Este caso, y otros que veremos, evidencian que un desafiliado es un trabajador disponible para trabajar al "precio" que sea pues su supervivencia se juega en el día a día. La negación de la afiliación es al tiempo la negación del cuidado de sí mismo.

Por otro lado, la condición móvil de los jornaleros que van siguiendo las cosechas entre los diferentes territorios eleva la vulnerabilidad de estos trabajadores al riesgo de contagio. Éste es caso del contagio habido en uno de los autobuses de una Empresa de Trabajo Temporal radicada en la Región de Murcia y especializada en trasladar jornaleros inmigrantes a Francia para la recolección de las cosechas ${ }^{20}$. Otro caso ha sido el de una jornalera inmigrante ecuatoriana, que no permitiéndose dejar de trabajar para no perder su jornal diario (otro caso de negación del cuidado de sí mismo), terminó ocasionando un importante contagio en Totana que reveló las pésimas medidas de seguridad en las furgonetas y autobuses con las que las Empresas de Trabajo Temporal trasladan a jornaleros por todo el territorio regional y en las cuales no se respetan las distancias de seguridad"2. La Consejería de Sanidad reconoció que "no hay un control adecuado en la movilidad entre trabajadores del campo que acuden desde zonas donde hay transmisión comunitaria"22. Las Empresas de Trabajo Temporal, un pivote central de la devaluación salarial en el campo murciano, se han convertido en la principal fuente de riesgo de contagio de la COVID-19 para los trabajadores agrícolas.

A mediados de julio, la patronal agraria y los sindicatos rompieron las negociaciones de los convenios colectivos del campo por el desacuerdo respecto a la implementación de la subida salarial del SMI. Las asociaciones de jornaleros inmigrantes, muy especialmente las vinculadas al colectivo marroquí, han organizado manifestaciones en Torre

\footnotetext{
Véase https://www.eldiario.es/desalambre/singapur-pais-modelo 1 6058408.html. Consultado 12/07/2020

https://sociologiaencuarentena.tumblr.com/post/615087502222655 $\overline{4} 88 /$ las-personas-esenciales

"Sigue aumentando el número de contagios conocidos entre los jornaleros que fueron a hacer la campaña de fruta y verdura a distintas localidades francesas en las pasadas semanas con la ETT murciana Terra Fecundis. Según ha confirmado la Consejería de Salud, ya son diez los trabajadores que han dado positivo al test de coronavirus y cerca de 60 guardan cuarentena en la Región de Murcia, que tras este último brote ha instado al Ministerio del Interior a incrementar los controles en la circulación de trabajadores del campo" (https://www.laverdad.es/murcia/decenas-jornaleros-region-20200611003521-ntvo.html).

21 "Isabel, la jornalera que ha bloqueado Totana: fue a trabajar con síntomas para pagar la carrera de su hijo. Durante más de tres semanas, esta ecuatoriana continuo recogió fruta en una empresa temporal que no cumplía con las normas de prevención y distanciamiento" (https:/www.elespanol. com/reportajes/20200527/isabel-jornalera-bloqueado-totana-trabajar-sintomas-carrera/492951905_0.html).

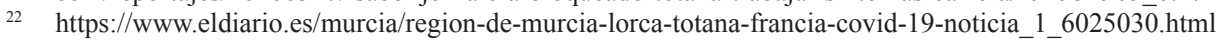


Pacheco y Lorca con reivindicaciones que abarcan desde la política laboral -subida del SMI- hasta la política migratoria - proceso de regularización extraordinario para los inmigrantes "sin papeles"-. Los sindicatos han anunciado movilizaciones para el otoño ${ }^{23}$.

\subsection{Los asentamientos informales de los enclaves de invernadero de Almería y de los campos de fresa en Huel- va: la negación del cuidado}

Tanto alrededor de los invernaderos de hortalizas de Almería como de los campos de fresas de Huelva se suceden los asentamientos informales o chabolas de miles de jornaleros inmigrantes, muchos de ellos con estancia irregular en España. Se trata de un "ejército de mano de obra en la reserva" al que acudir cuando acucian las puntas de trabajo en la recolección y el "mercado formal" de jornaleros regulares es insuficiente para atender a esta necesidad acuciante. Las franjas más desafiliadas de los inmigrantes regulares también pueden vivir en estos asentamientos dado que sus parcos ingresos no les permiten optar por una residencia formal.

Según el sindicato SOC-SAT, hay unas 7000 personas viviendo en los asentamientos informales de Almería, 4000 en la comarca oriental de Níjar y unas 3000 en otros núcleos del Poniente almeriense. Sólo en Níjar hay unos 90 asentamientos. Algunos como Barranquete, Cortijo Domingo y Los Nietos son auténticos poblados. La mayor parte de los pobladores de estos asentamientos son marroquíes, aunque también se da una importante presencia de subsaharianos. Las OnG,s como Médicos del Mundo o Cruz Roja han denunciado el estado de estos asentamientos: "En ninguno de los casos las viviendas reúnen las condiciones mínimas de habitabilidad e higiene. A la escasez de espacio y la precariedad de estas infraviviendas, hay que añadir la falta de agua potable y de canalizaciones para evacuación de aguas. En gran parte de los asentamientos no se realiza la retirada de basura. Las dificultades sanitarias son múltiples, típicas de cualquier asentamiento chabolista o peor incluso: sometidos a temperaturas extremas -especialmente en verano en esta zona, llegando a superar los $45^{\circ}$-, sin electricidad en algunos de ellos lo que dificulta la conservación de los alimentos; sin recogida de residuos ni acceso a agua potable. Todo esto unido a la dificultad de acceso a los centros de salud de la zona, por la lejanía y falta de medios de transporte" (Médicos del Mundo, 2017). También han señalado las condiciones de extrema vulnerabilidad en las que viven muchas mujeres en estos asentamientos: "En su gran mayoría son mujeres magrebíes que habitan los asentamientos y han llegado a España a través de contratos realizados por españoles en Marruecos para el trabajo en los almacenes o para la recogida de la fresa en Huelva. Médicos del Mundo, a partir de sus intervenciones sociosanitarias con estas poblaciones, ha podido detectar que muchas de estas mujeres marroquíes son susceptibles de ser víctimas de trata, dado que en su mayoría han sido engañadas para dejar su país (ofreciendo contratos de 3 a 6 meses) convenciéndolas de que se les va a procurar residencia y trabajo legales en España. Al llegar a nuestro país, son trasladadas a Almería donde se ven solas -sin vínculos familiares ni sociales- y sin residencia, ni trabajo. En esta situación de extrema vulnerabilidad la única salida que se les ofrece es convivir con un compatriota. De esta manera, las redes que están operando entre Almería y otras zonas de Andalucía y Marruecos, proporcionan a los hombres solteros que viven en los diseminados, mujeres que se ocupan de las tareas domésticas y con quienes mantener relaciones sexuales. Médicos del Mundo ha podido detectar, en sus intervenciones con estas mujeres, síntomas de maltrato físico y psicológico, y ha podido registrar que existen muchas informaciones sobre la presencia de prostitución cerca de los asentamientos, en las cortijadas y diseminados (principalmente de mujeres procedente de Nigeria, Ghana o Guinea Ecuatorial)" (Médicos del Mundo, 2017).

En el enclave fresero de Huelva la situación es muy similar: "en Huelva se cuentan hasta 5.000 personas en casi 50 asentamientos, según distintas entidades sociales. En España suman 15.000 entre este y otros polos como Almería y Murcia, según la Fundación Cepaim" (Abril, 2020) ${ }^{24}$. Durante los meses del estado de alarma sanitario, la Asociación de Trabajadores Africanos de Huelva no cesó de denunciar las condiciones precarias de habitabilidad en las que malvivían (y malviven) cientos de jornaleros inmigrantes asentados en auténticas chabolas en las inmediaciones de los campos de fresas en Huelva. "La mayoría de temporeros viven en albergues, cortijos, pisos compartidos y poblados prefabricados de las grandes explotaciones. Las chabolas solo muestran los márgenes del sistema. Pero en la zona se superponen capas de abusos más sutiles con cierto grado de tolerancia, pues si uno protesta, siempre hay otro dispuesto a llenar la vacante. Los braceros soportan jornadas más largas de lo pactado en convenio; amenazas por bajo rendimiento; se les amedrenta con echarles, con días sin empleo; las empresas calculan a la baja las horas y de las nóminas detraen conceptos ilegalmente, como el alojamiento" (Abril, 2020).

Dadas las condiciones de los poblados informales donde se hacinan los jornaleros inmigrantes de Almería y Huelva (extensibles a otras regiones donde, aunque sea en menor cuantía, se reproduzca una situación análoga), la crisis sanitaria de la COVID-19 no vino sino a agravar mucho más la situación. ¿Cómo iban a poder cumplir con las prescripciones sanitarias esos trabajadores hacinados en infraviviendas sin acceso a servicios básicos como el agua potable y sin dignidad laboral por la continua laceración de sus derechos de ciudadanía? ${ }^{25}$

23 Sobre la ruptura de las negociones de los convenios colectivos del campo: https://www.ondacero.es/emisoras/murcia/murcia/noticias/los-sindicatos-auguran-un-otono-caliente-en-el-campo-murciano 202007105f0819e38fbe650001b3b4c5.html. Sobre las protestas convocadas por las asociaciones de trabajadores inmigrantes: https:/www.laverdad.es/murcia/torrepacheco/inmigrantes-marroquies-toman-20200711202543-nt.html

24 Seguramente el mejor reportaje de la prensa española sobre la situación de estos jornaleros lo escribió Guillermo Abril con el título "Jornaleros de la Pandemia" en El País: https://elpais.com/elpais/2020/07/08/eps/1594218155_607566.html.

25 "El confinamiento bajo el mar de plástico de Almería: "Les llevamos jabón, pero no tienen agua. Sindicatos y entidades sociales alertan de que los asentamientos de trabajadores agrícolas viven la amenaza del coronavirus hacinados y sin suministros básicos, lo que impide cumplir con las 
El trabajo requerido por la recolección de la fresa no solamente es cubierto por la mano de obra asentada en las reservas de los poblados chabolistas. Desde hace años funciona un Programa de Trabajadores Contratados en Origen que es considerado como "modélico" en las políticas migratorias. Es un programa que trae cada temporada a miles de mujeres jornaleras. En sus inicios procedían de los países de Europa del Este y en los últimos años se ha optado por Marruecos. Para esta temporada se preveía la llegada de 16.500 mujeres, pero finalmente el cierre de fronteras por la crisis sanitaria hizo que solamente accedieran 7000. La investigación realizada desde hace tiempo por sociólogas y antropólogas críticas ha servido para evidenciar el carácter patriarcal y neocolonial que este tipo de contratación conlleva, desde el momento de la misma selección en origen de las trabajadoras, hasta las condiciones de residencia y convivencia en los alojamientos donde son alojados por los empleadores (Reigada, 2015; Moreno y Hellio, 2017). También la crisis sanitaria ha iluminado la realidad de "la contratación en origen" al dejar literalmente encerradas a estas siete mil mujeres jornaleras marroquíes que, una vez finalizada la recolección de la fresa, no pudieron retornar a su país por el cierre de fronteras ${ }^{26}$. Finalmente, el regreso se organizó a mediados de julio y los empresarios anunciaron que para próximas temporadas iban a buscar otras alternativas para realizar la contratación en origen, dadas las dificultades puestas por Marruecos en la organización del retorno de las mujeres jornaleras. En la economía-mundo, siempre hay periferias de mano de obra disponible para la sobreexplotación.

\subsection{La movilidad territorial de los jornaleros: la campaña de la fruta en Lleida y el contagio del virus}

Los municipios de la fruta de la provincia de Lleida reciben cada temporada en los meses entre mayo y julio a miles de jornaleros inmigrantes para la recolección del producto. Como cada año se pone de manifiesto la insuficiencia del alojamiento, el hacinamiento de las viviendas jornaleras e incluso las situaciones de infravivienda. Dado el llamamiento que hicieron las autoridades por la escasez de mano de obra para garantizar la recolección de la cosecha, la temporada de este año ha sido especialmente cuantiosa en cuanto al número de jornaleros venidos de fuera. Muchos de ellos tuvieron que pernoctar por las calles y campos. En plena crisis sanitaria, el virus de la COVID-19 encontró un escenario ideal para su circulación y contagio.

El contagio ha sido de una extrema gravedad, hasta el punto de que unas semanas después de finalizar el estado de alarma, la Generalitat tuvo que decretar el confinamiento de los 38 municipios que componen la comarca leridana del Segriá, culpándose de la situación desde algunos medios a las supuestas "malas prácticas de los temporeros" -por compartir agua o no utilizar mascarillas). La vulnerabilidad de los jornaleros inmigrantes sin alojamiento formal e itinerante entre cosechas es la cuestión de fondo de la situación que se está viviendo en Lleida:

"Morales-Rull [director de la unidad de COVID-19 del Hospital Arnau de Vilanova de Lleida] apunta a que los servicios epidemiológicos se han visto superados por la dificultad de rastrear los contactos de los temporeros y advierte de que una situación como esta requiere de medidas que van más allá del ámbito sanitario: "Percibimos que un poco antes de San Juan [23 de junio] empezaban a aumentar los casos. O sea que el principio del brote podríamos situarlo en el 22-23 de junio. Es un perfil que ha ido cambiando cronológicamente. Primero era el de trabajadores vinculados al sector cárnico. Eran pacientes que trabajaban en un matadero, inicialmente los que estaban directamente en la parte del género y posteriormente a los del resto de la cadena. Una parte era migrante ya establecido aquí, muchos de ellos viven en pisos pequeños y por lo tanto nos dimos cuenta que no solo el entorno laboral es una fuente de contagio, sino que también lo es el entorno social. Luego vino el brote de la residencia, que fue muy fácil de tratar y controlar, y después se dio el gran salto con el del sector hortofrutícola. En este caso es todo más complejo porque ya no es el trabajo en una fábrica como pasaba con la empresa cárnica, sino que se dispersan mucho más. Y también ha llegado al resto de la cadena, la manipulación, almacenaje, etc. Vemos que las personas que viven hacinadas o incluso en la calle es un foco de contagio importante. Ahora, un $20 \%$ de los casos son los llamados comunitarios, aquellos en que ya no está clara la vía de confinamiento"27.

Al igual que en los poblados informales de Almería y Huelva, la situación en la que están los jornaleros de la comarca del Segriá imposibilitaba adoptar condiciones higiénicas mínimas y de cuidado (negación estructural del

medidas de prevención" (https://www.eldiario.es/andalucia/confinamiento-plastico-almeria-llevamos-jabon_1_1211813.html).

"A los jornaleros inmigrantes de Huelva nos han dejado solos, como siempre. Side dice que han sido los voluntarios y activistas locales quienes han proporcionado mascarillas y alcohol durante el confinamiento. Los primeros días de marzo, cuando se declaró el estado de alarma, solo la Unidad Militar de Emergencia (UME) hizo acto de presencia en los asentamientos, informando sobre cómo combatir el virus y protegerse de posibles contagios. Una información más que inútil cuando tu techo es un plástico, no tienes agua, ni luz, ni un grifo a mano ni posibilidad de guardar la distancia de seguridad dentro de una chabola en un asentamiento que triplica su aforo en plena temporada" (https://elpais.com/sociedad/2020-07-06/ nos-han-dejado-solos-como-siempre.html). Consultado 12/07/2020.

26 "Un retorno que hasta el momento no tiene fecha, una situación que ha interpelado hasta a Interfresa, patronal del sector, para mandar otra carta más a la embajadora Beyaich. En declaraciones a la agencia Europa Press, su gerente, Pedro Marín, ha alertado de que los empresarios estarían "al límite de sus posibilidades". Pues estos empleadores llevarían más de un mes “avituallando a estas personas, garantizándoles la vivienda". El portavoz de Interfresa manifestaba la preocupación de las empresas por evitar sufrimiento a las temporeras. "Están dejadas, varadas, olvidadas: están atrapadas, muy estresadas después de tantos meses de trabajo que se lo han comido todo porque no han tenido relevo". "Están dejadas, varadas, olvidadas: están atrapadas, muy estresadas después de tantos meses de trabajo que se lo han comido todo porque no han tenido relevo", resume José Antonio Brazo de la sección onubense del Sindicato Andaluz de Trabajadores (SAT). Al estar alojadas en fincas dispersas muy lejos de los núcleos urbanos, la sensación de abandono y de estar atrapadas se intensifica. Para este sindicalista, que cuenta haber hecho ayer 9 de julio varios viajes para acercar a estas temporeras al supermercado, este es uno de los problemas principales pues deja a las mujeres expuestas, tanto si caminan solas, como si intentan que les acerquen en coche, a todo tipo de abusos. "He hablado con muchas de ellas y me han dicho que están deseando volver a Marruecos", afirma" (https://www.elsaltodiario.com/temporeros/7.000-temporeras-marroquies-atrapadas-y-ningun-plan-retorno). Consultado 12/07/2020.

27 En https://www.eldiario.es/catalunya/jose-luis-rull-lleida-ahora-banco-pruebas-pasar-territorios-morales_128_6090707.html 
cuidado $)^{28}$. Además, dado que se trata de jornaleros itinerantes, muchos de ellos rechazaron someterse a control sanitario pue su prioridad era trabajar y no perder ni un día de jornal (negación del cuidado del sí mismo). En definitiva, lo que la crisis sanitaria una vez y otra pone de manifiesto es que allí donde se concentran poblaciones socialmente vulnerables desde el punto de vista de la precariedad laboral (jornaleros), residencial (chabolismo) o jurídica (inmigrantes irregulares) devienen territorios especialmente propensos al riesgo de contagio. La condición móvil de los jornaleros que van siguiendo las cosechas entre los diferentes territorios eleva la vulnerabilidad de estos trabajadores al riesgo de contagio: El doctor Morales-Rull del Hospital Arnau de Vilanova de Lleida también señala a la movilidad de los jornaleros como un problema para el control del virus: "Lleida es ahora el banco de pruebas, pero esto puede pasar en otros territorios del Estado. Toda la gente que tenemos viviendo en la calle se va a marchar a otros puntos" 29 .

La situación de Lleida y la rapidez con la que se extendió el brote vírico llevó a la experta Helena Legido-Quigley (profesora asociada de la London School of Hygiene and Tropical Medicine, de la Universidad Nacional de Singapur y visitante de la Universidad de Lleida), a compararla con lo acontecido en Singapur en los dorms de los trabajadores inmigrantes:

"Singapur fue el primer caso en un país donde parecía que estaba controlado. Aunque yo creo que ha habido dos epidemias, la primera se controló, se hicieron test, seguimiento de contactos, estaban muy bien preparados con el SARS. Y luego el descontrol a raíz de empezar las infecciones entre los inmigrantes. Es un caso que se podía prever, pero se les pasó a las autoridades. Afecta a gente que vive en condiciones de hacinamiento. Son unos 300.000 trabajadores que viven en lo que llaman dorms, donde cada habitación la comparten unas 20 personas, con lo que no pueden tener la separación necesaria. Antes de la COVID-19 ya preocupaba mucho las condiciones de estas personas en la propagación de enfermedades como la tuberculosis. Como el Gobierno tiene la preparación reaccionó, pero se descontroló la situación, con más de 40.000 casos de inmigrantes. Dicen que está controlado, pero no del todo, siguen teniendo decenas de casos al día todavía.

La semejanza con Lleida y Aragón radica en las condiciones de vivienda en hacinamiento. Es diferente en el sentido de que en Singapur la mayoría son trabajadores de la construcción y en Lleida son temporeros. Pero cuando sucedió en Singapur lo primero que pensé es que era algo que podía ocurrir también aquí. En España ya sabíamos que podía pasar. Pero en Lleida es incluso peor: hay gente viviendo en la calle, sin contrato. En Singapur sí tienen que tener permiso de trabajo, así que es más fácil para hacer un seguimiento. Aquí es más complicado porque el trabajador no tiene papeles ni tarjeta sanitaria"30.

\section{Conclusiones}

La consideración de trabajadores "esenciales" a los asalariados agrícolas durante el estado de alarma sanitaria por la pandemia de la COVID-19 posibilitó una visibilización de la precariedad y desafiliación de estos trabajadores. Estas condiciones precarias y desafiliadas han imposibilitado estructural y subjetivamente el cuidado de sí mismos, lo que les ha empujado a protagonizar numerosos brotes víricos por toda la geografía estatal una vez finalizado el periodo de confinamiento.

Al mismo tiempo se ha puesto de relieve un problema de reconocimiento (Honneth, 2019) y una lógica de desprecio. De tal forma que "la nueva normalidad" se está viendo salpicada de un buen número de "luchas por el reconocimiento" protagonizadas por los asalariados inmigrantes con reivindicaciones que abarcan desde el reconocimiento de sus derechos laborales (subida del SMI y otros) hasta el reconocimiento de la residencia legal en el país mediante un proceso de regularización extraordinaria ${ }^{31}$. Su visibilización como trabajadores "esenciales", y el contraste con su existencia desafiliada, les ha posibilitado un proceso de acumulación de capital simbólico con el que desarrollar estas luchas por el reconocimiento.

Bajo esta problemática de reconocimiento subyace la materialidad del funcionamiento económico de los enclaves agroexportadores que se basa no en la explotación sino en la sobreexplotación, es decir, no en la producción de producción de plusvalor, sino en la usurpación del valor del trabajo inmigrante a través de modalidades de infraempleo y sobreintensificación de los ritmos de trabajo. La disponibilidad de una mano de obra posibilitada por los flujos migratorios para el trabajo duro e intenso a bajo precio posibilita una organización social de la producción fundamentada en la usurpación del trabajo ajeno y legitimada por la naturalización de sus cualidades étnicas. La "naturaleza del cuerpo inmigrante" es lo que normaliza el hecho de trabajar por debajo de los estándares medios de la población española, así como también la infravaloración de sus necesidades para la reproducción social (vivienda, transporte,

\footnotetext{
28 "El drama de los temporeros en Lleida: "Vivimos como animales". En plena crisis del coronavirus, se agravan las insalubres condiciones en las que viven los trabajadores del campo. Muchos rehúyen los controles sanitarios por miedo a perder el empleo y quedarse atrapados en Ponent" (https://www.elperiodico.com/es/sociedad/20200703/el-drama-de-los-temporeros-en-lleida-vivimos-como-animales-8025638?utm_source=facebook\&utm medium=social\&utm campaign=btn-share). Consultado 12/07/2020

29 En https://www.eldiario.es/catalunya/jose-luis-rull-lleida-ahora-banco-pruebas-pasar-territorios-morales_128_6090707.html

30 En https://elpais.com/sociedad/2020-07-12/cataluna-es-la-demostracion-de-que-los-sistemas-no-estan-preparados.html. Consultado 12/07/2020.

31 No deja de ser paradójico que el gobierno español siga sin abrir un proceso de regularización extraordinaria para miles de trabajadores inmigrantes sin papeles que, sin embargo, fueron movilizados durante el confinamiento cuando se constató un problema de escasez de mano de obra que impedía la recogida de las cosechas.
} 
útiles de consumo, etc.). Ciertamente, y en términos generales, hay una aceptación por parte de los propios inmigrantes de estas condiciones salariales pues al menos ven garantizadas su subsistencia diaria y pueden realizar un cierto cálculo racional comparativo de su ganancia en España respecto al país de origen. En definitiva, la condición inmigrante naturaliza unas relaciones sociales de sobreexplotación que también son objeto de la inspección de trabajo y de rechazo por parte de administraciones y empresas.

Hoy la desafiliación social de los asalariados agrícolas y de otros colectivos sociales igualmente precarios remite a la Cuestión Social de nuestro tiempo. Este término es muy importante en la cultura política europea desde al menos finales del siglo XIX. El sociólogo Robert Castel propone una definición ejemplar en estos tiempos en los que un virus ha encontrado su mejor modo de circulación entre los pliegues de la precariedad vital y laboral: "la cuestión social es una aporía fundamental en la cual una sociedad experimenta el enigma de su cohesión y trata de conjurar el riesgo de su fractura. Es un desafío que interroga, pone de nuevo en cuestión la capacidad de una sociedad (lo que en términos políticos se denomina una nación) para existir como un conjunto vinculado por relaciones de interdependencia”. (Castel, 1997: 20)

La crisis sanitaria actual nos interpela de nuevo a confrontarnos con las fracturas que desgarran el cuerpo social y que no son otras que las derivadas de la desafiliación. Es un momento propicio para la Cuestión Social. Cuando las sociedades históricamente han querido conjurar el riesgo de sus fracturas siempre ha sido a través de conquistas en el terreno de los derechos sociales y laborales.

\section{Bibliografía}

Abril, G. (2020). "Jornaleros de la pandemia”, El País Semanal, 12 de julio.

Arnalte, E., Camarero, L. y Sancho, R. (2006). Los regantes. Perfiles productivos y socioprofesionales, MAPA, Madrid.

Bauman, Z. (1994). Pensando sociológicamente, Ediciones Nueva Visión, Buenos Aires, Argentina.

Bourdieu, P. (1999). Meditaciones Pascalianas, Anagrama, Barcelona.

Castel, R. (1997). Las Metamorfosis de la Cuestión Social, 1997, Paidós, Barcelona.

Castellanos, M. L. y Pedreño, A. (2001). "Desde Elejido al accidente de Lorca: las amargas cosechas de los trabajadores inmigrantes en los milagrosos vergeles de la agricultura mediterránea", Sociología del Trabajo, Nueva Época, no 42, pp. 3-32.

Checa, J. C. y A. Arjona (2005). "El vecino no deseado. Situación residencial de los inmigrantes africanos en Almería (España)", Revue européenne des migrations internationales, vol. 21, $\mathrm{n}^{\circ} 3$, pp. 179-207.

Etxezarreta, M. (1994). "Trabajo y agricultura: los cambios del sistema de trabajo en una agricultura en transformación", Agricultura y Sociedad, $\mathrm{n}^{\circ}$ 54, pp. 533-564, Madrid.

Fernández, F. (2017). “¿Está aumentando la extrema derecha en el medio rural?”, Soberanía Alimentaria, Biodiversidad y Culturas, $\mathrm{n}^{\mathrm{o}} 30$ [https://www.soberaniaalimentaria.info/numeros-publicados/61-numero-30/476-portada-30]

Friedland, W. (2001). "Reprise on Commodity Systems Methodology", International journal of Sociology of Agriculture and Food, vol. 9, 1, pp. 82-103.

Gadea, E.; Pedreño, A. y Castro, C. (2017). "Producing and mobilizing vulnerable workers: the agribusiness of the region of Murcia (Spain)", en Corrado, A. y Castro, C. y Perrotta, D. (ed.), Migration and Agriculture. Mobility and change in the Mediteranean Area (pp. 79-949), Routledge, London and New York.

Gereffi, G. (2005). "The Global Economy: organization, governance and development”, en Smelser, N. J. y Swedberg, R. (ed.). The Handbook of Economic Sociology (pp. 160-182), Princeton University Press y Russell Sage Foundation, Princeton, NJ.

Gutiérrez, R. (2009). "La dinámica de la pobreza de trabajadores", Revista Internacional de Organizaciones, 3, pp. 49-70.

Honneth, A. (2019). Reconocimiento. Una historia de las ideas europea, Akal, Madrid.

Laval, C. y Dardot, P. (2013). La Nueva Razón del Mundo, Gedisa, Barcelona.

Linhart, D. (1997). La modernización de las empresas, PIETTE del CONICET, buenos Aires.

Linhart, D. (2013). ¿Trabajar sin los Otros?, Publicaciones de la Universidad de Valencia, Valencia.

Marx, K. (1984). El Capital. Libro Segundo: El Proceso de Circulación de El Capital, Siglo XXI Editores, Madrid.

Marsden, T. (1997). "Creating space for food: the distinctiveness of recent agrarian development”, en Goodman, D. y Gatts, M. (eds). Globalising Food. Routledge, London and New York.

Médicos del Mundo (2020). "A las ocho de la mañana todos los inmigrantes son pocos. A las ocho de la noche sobran todos": condiciones de vida en los asentamientos chabolistas en e Poniente Almeriense", Informe de Prensa.

Moreno, J. y Hellio, E. (2017). "Las jornaleras de la fresa en Andalucía y Marruecos. Hacia un análisis feminista de la globalización agroalimentaria", Soberania Alimentaria, Biodiversidad y Culturas, $\mathrm{n}^{\circ} 30$ [https://www.soberaniaalimentaria.info/ numeros-publicados/61-numero-30/480-las-jornaleras-de-la-fresa-en-andalucia-y-marruecos]

O.I.T. (2020). Perspectivas sociales y del empleo en el mundo. Tendencias 2020, Organización internacional del Trabajo.

Pedreño, A. (1999). Del jornalero agrícola al obrero de las factorías vegetales, Ministerio de Agricultura, Pesca y Alimentación, Madrid.

Pedreño, A. (2005). “Sociedades etnofragmentadas”, en Pedreño, A. y Hernández, M. (coord.). La Condición Inmigrante. Exploraciones e Investigaciones desde la Región de Murcia (pp. 75-106), Aula de Debate, UMU, Murcia. [https://www.researchgate.net/publication/28304129_Sociedades_etnofragmentadas] 
Pedreño, A. (2014) (coord.). De cadenas, migrantes y jornaleros. Los territorios rurales en las cadenas globales agroalimentarias, Talasa, Madrid.

Pedreño, a. (2020). "Un momento durkheimiano y un momento marxiano en la crisis sanitaria de la COVID-19", Trabajo y Sociedad, n 35, vol. XXI, pp. 223-233, Argentina, Santiago del Estero.

Pedreño, A. y Riquelme, P. J. (2006). "La condición inmigrante de los nuevos trabajadores rurales", Revista Española de Estudios Agrosociales y Pesqueros, $\mathrm{n}^{\circ}$ 211, pp. 189-238.

Reigada, A. (2015). “¿Cultivos de primor? Feminización y sexualización del trabajo en los campos de fresa en Andalucía”, en Sánchez, M. J. y Lara Flores, S. M. (coord.): Los programas de trabajadores agrícolas temporales: ¿una solución a los retos de las migraciones en la globalización?, Universidad Nacional Autónoma de México-Instituto de Investigaciones Sociales/ Programa de Apoyo a Proyectos de Investigación e Innovación Tecnológica (PAPIIT), México, pp. 319-354 [http://ru.iis. sociales.unam.mx:8080/jspui/handle/IIS/5229].

Uxó. J., Febrero, E. y Bermejo, F. (2015). "Reforma Laboral, devaluación salarial y empleo: una perspectiva macroeconómica", Revista de Economía Laboral, 12, pp. 201-247. 